\title{
IN THE MUSEUM
}

\section{A J Ryan \& A Gosling (University of Natal, Durban)}

Thanks to a generous donation by Ms. Joan Law, the Museum of Classical Archaeology has been able to purchase five Roman coins. Each of the coins illustrates an interesting aspect of Imperial culture and may be used to illustrate various aspects of Roman history. Furthermore, although the extent to which the iconography on coinage was under direct imperial control is debatable, a comparison with current imperial iconography and sentiment can be illuminating in assessing the public image of the emperor.

Three of the coins represent the transition from Republic to Principate. The first is a silver denarius $^{1}$ struck around $41 \mathrm{BC}$ featuring on the obverse Antony's bare head to right and on the reverse the bare head of Octavian to right. The obverse inscription reads $M$ ANT IMP AVG III VIR R P C ${ }^{2} / \mathrm{M}$ BARB ... [AT] Q P. ${ }^{3}$ III VIR R P C refers to Antony's appointment by the Lex Titia of $43 \mathrm{BC}$, together with Octavian and Lepidus, as a triumvir explicitly charged with the restructuring of the republican constitution. This office would be abused by proscriptions and other unconstitutional measures - eventually being reconstituted illegally in $37 \mathrm{BC}$, the year after its official term had lapsed. ${ }^{4}$ The other name on the obverse, that of the moneyer who issued the coin, Marcus Barbatus, holds little interest save that he was a friend of both Caesar and Antony.

The reverse reads CAESAR IMP PONT III VIR R P C. The earliest coinage featuring Octavian refers to him as CAESAR IMP - the honorific Imperator reflecting his defeat, together with Anthony, of the tyrannicides Brutus and Cassius at Philippi in 42 BC. Later, CAESAR IMP is replaced by CAESAR DIVI $F$ after the deification of Julius Caesar had provided Octavian with the opportunity to advertise his legitimacy as leader of the Caesarian faction. After the defeat of Antony, Octavian uses IMP CAESAR on most of his coins, virtually adopting the title of Imperator as a praenomen. ${ }^{5}$ The inscriptions on both sides of the coin also illustrate the value attached to the state religion as a propaganda tool - a fact that was well understood by Julius Caesar who issued a series of coins illustrating symbols of the priesthood on the reverse. ${ }^{6}$ On our coin, both Antony and Octavian have their priesthoods advertised - AVG (augur) and PONT (Octavian was appointed pontifex in $47 \mathrm{BC}$, when he was only 15). The other triumvir, Lepidus, was pontifex maximus - a title that was passed on to Augustus on the former's death in 12 BC. Although our coin was issued by Antony, a number of coins featuring two triumvirs were issued by each of the colleagues from $43 \mathrm{BC}^{7}$ until their relationship soured.

1. Plate 1.a. \& b.: Durban 2004.45, diameter 17.8 mm, weight 2.76 g. (RRC 517/2, RSC 8, Syd. 1181)

2. Marcus Antonius Imperator Augur Triumvir Reipublicae Constituendae

3. Marcus Barbatus

4. Syme 1939: 113

5. Syme 1939: 225. Evidence for this is not only abundant in the coinage, but contemporary and later authors also refer to Octavian as Imperator on occasion (Rubincam 1992).

6. $R R C 443 / 1$, Syd 1006. obverse: the legend CAESAR in exergue, an elephant $r$. trampling a serpent; reverse: simpulum, aspergillum, axe and apex (symbols of the office of pontifex maximus). The coin was issued to commemorate Julius Caesar's appointment as the chief pontiff.

7. For example: Octavian and Antony on a series of aurei from 43 BC (RRC. 493 /1b, Syd 1167: obverse C CAESAR IMP III VIR R P C PONT AV, bare head of Octavian r.; reverse M ANTONIVS IMP III VIR R P C AVG, bare head of Antony to r), Lepidus and Octavian on a series of aurei from $42 \mathrm{BC}(R R C 495 / 2 \mathrm{a}$, 
Octavian also appears on two copper coins in our recently acquired lot, but in his later guise as Augustus. The first, dating from around $15 \mathrm{BC},{ }^{8}$ has on the obverse an oak wreath, around which is inscribed AVGVSTVS TRIBVN[IC] POTEST, and a countermark stamped IMP; on the obverse is the inscription naming the moneying magistrate: C PLOTIVS RVFVS III.VIR A A A F F F $^{9}$ around the senatorial seal SC, with two countermarks: one stamped AVG (Augustus) and the other TI.C.A (probably Tiberius Claudius Augustus). TRIBUNIC POTEST refers to Augustus' assumption of tribunician power in $23 \mathrm{BC}$, which made the princeps the direct protector of the masses, and also conferred sacrosanctity upon his person. An interesting feature of this coin is that Augustus does not appear in portrait - the portrait of the emperor would become a standard feature of the obverse of subsequent imperial coinage. However, the importance of the head on the obverse of the coin as a sign of imperial guarantee was still a novelty. Instead, the oak wreath, symbolising Augustus as saviour of the state, served this purpose.

The present example represents the first type to be minted in Rome - the earliest examples of which date from $19 \mathrm{BC}$ and the latest of which are from $4 \mathrm{BC}$. The format of the dupondius from this period was exactly as our piece on the obverse, with the reverse bearing an inscription indicating the names of the tresviri monetales surrounding a senatorial seal. ${ }^{10}$ The latter mark indicates that, as one of numerous nominal tokens of Augustus' adherence to republican ideals, the senate controlled the minting of copper currency (while higher denominations were, of course, under imperial control). However, our coin looked suspiciously like copper ${ }^{11}$ rather than orichalcum - the zinc-copper alloy from which dupondii are made. The museum is grateful to Dr Andrew Kindness who carried out an electron microscope examination of the surface of the coin. However, the resulting spectrum was open to a number of interpretations. While the surface did contain amounts of zinc and lead, the proportion was less than would have been expected for orichalcum. In fact, the proportion of copper on the surface of the coin was almost identical to the proportion of copper found on the surface of an as. Furthermore, zinc and lead are typically present in similar proportions in copper that has been extracted from malachite or other carbonate ores. However, a surface scan is an unreliable indicator of composition of such heavily patinated artefacts. There do exist techniques capable of providing a definitive answer, but these are invasive and consequently the museum has decided that for the moment, it is content with the attribution of the coin as a dupondius. ${ }^{12}$

A final comment on the coin concerns the countermarks, which indicate that the coin was brought back into circulation. Official countermarks were stamped on coins (generally from the early empire) whose surface had become too worn to be recognisable - particularly during periods of economic difficulty. These marks are not uncommon on copper-based coinage, but the practice was rarely applied to higher denominations.

Syd. 1323: obverse LEPIDVS PONT MAX IIIV R P C, bare head of Lepidus r.; reverse CAESAR IMP III VIR R P C, bare head of Octavian r.)

8. Plate 1.c\&b: Durban 2004.46, diameter $27.45 \mathrm{~mm}$, weight $8.3 \mathrm{~g}$.

9. Gaius Plotius Rufus Triumvir Aere Argento Auro Flando Feriundo (also called triumvir monetalis). This was a republican college in charge of minting coins.

10. Carson (1990: 6)

11. from which asses are made.

12. following RIC 388 
The last of the Augustan coins, an as dating from $7 \mathrm{BC},{ }^{13}$ has on the obverse the bare head of Augustus (to right) around which is the legend CAESAR AVGVST PONT MAX TRIBUNIC POT. Again, the reverse features the senatorial mark SC surrounded by the legend of the moneying triumvir, M SALVIVS OTHO IIIVIR AAAFF. In addition to tribunician power, the inscription also advertises Augustus' accession to the position of pontifex maximus on the death of Lepidus in $12 \mathrm{BC}$. Having already gained control of almost every aspect of Roman society - economic mainly by virtue of his wealth plundered from Egypt, military through his control over most of the provinces and his pronominal title imperator, social through his tribunician power and auctoritas, and legal through his consular powers and control of the Caesarian faction - he was now also the chief representative of the state religion.

Our next two coins are from much later. The first is an as ${ }^{14}$ issued late in the reign of Commodus. ${ }^{15}$ The obverse features the head of Commodus laureate to right surrounded by the inscription L AEL AVREL COMM AVG P FEL. ${ }^{16}$ The reverse features a wreath surrounding the legend HERCVL/ROMAN/AVGV ${ }^{17}$ in three lines with a vertical club dividing. The young emperor, heir of Marcus Aurelius, is best known today for his megalomaniacal exploits in the film Gladiator. Indeed, much of this reputation is well deserved as the emperor's fortune and skill soon led the young man to believe that he was invincible. While the felix at the end of his name may be interpreted as a fitting sobriquet, the identification of himself as the Roman Hercules borders on hubris. While other emperors did display the iconography of their patron gods in their own portraits, Commodus portrayed himself as Hercules. Furthermore it has been observed that some of the nomenclature of Marcus Aurelius and Antoninus Pius has been dropped from coins from the end of his reign - further testimony to his increasing identification with Hercules as opposed to his temporal ancestors. ${ }^{18}$

The final coin, a silver denarius ${ }^{19}$ issued under Septimius Severus ${ }^{20}$ brings us closer to home as Septimius, having been born in Lepcis Magna, was African. The obverse has SEVERVS PIVS AVG around Septimius laureate to right; and the reverse continues with the theme of piety showing the emperor standing to left holding an olive branch and a scroll, surrounded by FVNDATOR PACIS. The coin was minted in 201 and the title Fundator Pacis (founder of peace) probably refers to Severus' defeat of the Parthians (198) in his second campaign against Rome's old enemy, after which he also adopted the title Parthicus Maximus. ${ }^{21}$ Although the emperor was fond of bestowing new titles upon himself, fundator pacis may not have been an empty honorific, since Severus' long reign brought some stability to an empire that was straining under intense competition between imperial pretenders. But much of this "peace" was enforced by brutality and purges of his opposition. Moreover his reforms, including the replacement of the Praetorian guard with Illyrian mercenaries and the

13. Plate 1. e. \& f.: Durban 2004.47, diameter $28.25 \mathrm{~mm}$, weight $9.1 \mathrm{~g}$ (RIC 431)

14. Plate 2. a. \& b.: Durban 2004.48, diameter $17.4 \mathrm{~mm}$, weight $3.4 \mathrm{~g}$ (RIC 251)

15. $161-192 \mathrm{AD}$, emperor from 180 after the death of Marcus Aurelius.

16. Lucius Aelius Aurelius Commodus Augustus Pius Felix.

17. Herculi Romano Augusto - To the Roman Hercules.

18. Clay (1982: 192)

19. Plate 2. c. \& d.: Durban 2004.49, diameter $18.02 \mathrm{~mm}$, weight $2.8 \mathrm{~g}$ (possibly BMC 330, RIC 265, RSC 205).

20. $145 / 6-211 \mathrm{AD}$, emperor from 193 after the death of Pertinax.

21. A title frequently appearing on coins either as SEVERVS AVG PART MAX or L SEPT SEV AVG IMP XI PART MAX — the IMP XI also referring to the Parthian victory. 
transformation of the office of Praetorian prefect into an administrative rather than military post, did not do much to rectify the inherent instability of the system. Furthermore, his attempt to legitimise the dynastic strength of his reign by promoting his sons Geta and Caracalla led to intense hostility between the heirs, the subsequent murder of Geta by his brother, and Caracalla's murderous reign. Ironically, Caracalla was himself murdered by the Praetorian prefect Macrinus, who became the next emperor.

The style of portraiture is quite typical of the latter half of the middle period of Septimius' reign (197-205). The idealised classicism is reflected in the curls around his forehead and the standard three-pronged beard. Our coin does not have the corkscrew locks falling down over the forehead that are popular on his earlier coins of this period and which represent the patron god of the African emperor - Serapis. ${ }^{22}$ Septimius remains an oddity. Not only did he spend most of his reign on campaign outside of Italy, but he seemed to take a greater interest in the eastern provinces than Rome, and he never broke free from his African roots.

The five coins here presented span three centuries of imperial history and are each, in their own right, interesting examples of the imperial public persona. Furthermore, they are excellent teaching aids and they will fit well into the lecturing schedule of the Classics programme. It remains only for us to thank Ms Law for her kind contribution to our collection.

\section{BIBLIOGRAPHY}

Apostoleris, N H 1980. Roman republican coins: Iconography and history. SAN 11, 52-58.

Apostoleris, N H 1981. Stylistic, iconographical and historical aspects of Augustan coinage. SAN 12, $44-48,55$.

Carson, R A G 1990. Coins of the Roman empire. London and New York: Routledge.

Clay, C L 1982. Towards a historical interpretation of the Roman coinage of Commodus: review of Keiser-Raiss, MR 1980. Die stadtrömische Münzprägung wehrend der Alleinherrschaft des Commodus. Munich. NC 19, 1-4.

$[R R C]$ Crawford, M H 1975. Roman republican coinage. Cambridge: Cambridge University Press. Hill, P V 1979. The coin-portraiture of Severus and his family from the mint of Rome. NC 19, 36-46.

[BMC] Mattingly, H 1976. Coins of the Roman empire in the British Museum volume V: PertinaxElagabalus. London: British Museum.

Rubincam, C 1992. The nomenclature of Julius Caesar and the later Augustus in the triumviral period. Historia 41, 89-103.

Sear, D R 1988. Roman coins and their values (revised edition). London: Seaby.

[RIC] Sutherland, C H V 1984. The Roman imperial coinage (revised edition). London: Spink.

[Syd] Sydenham, E A 1952. The Coinage of the Roman republic. London.

Syme, R 1939. The Roman Revolution. Oxford: Clarendon.

Wallace-Hadrill, A 1986. Image and authority in the coinage of Augustus. JRS 76, 66-87.

22. A more thorough discussion of Severan iconography can be found in Hill (1979:36-39). 

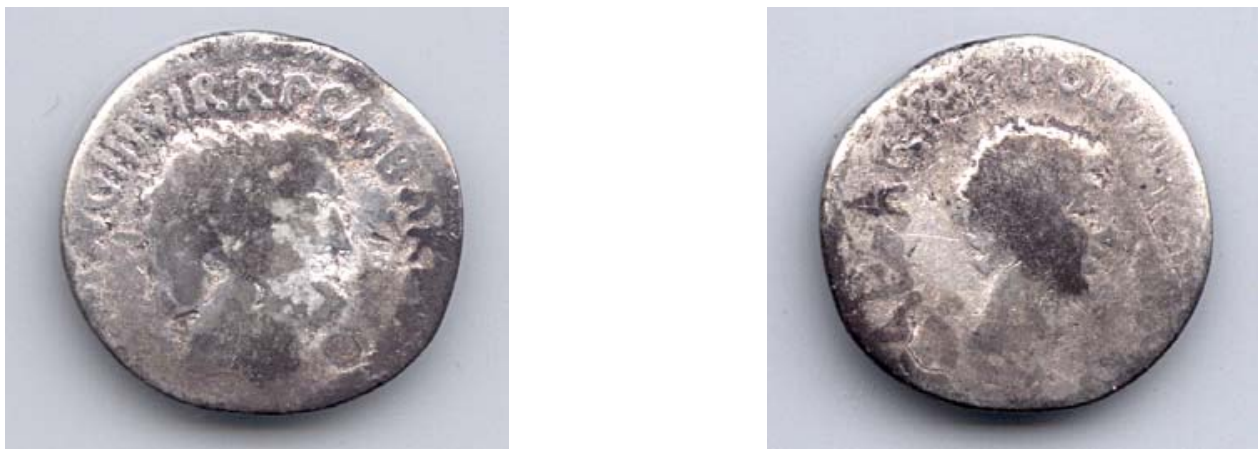

a.\& b. Durban 2004.45
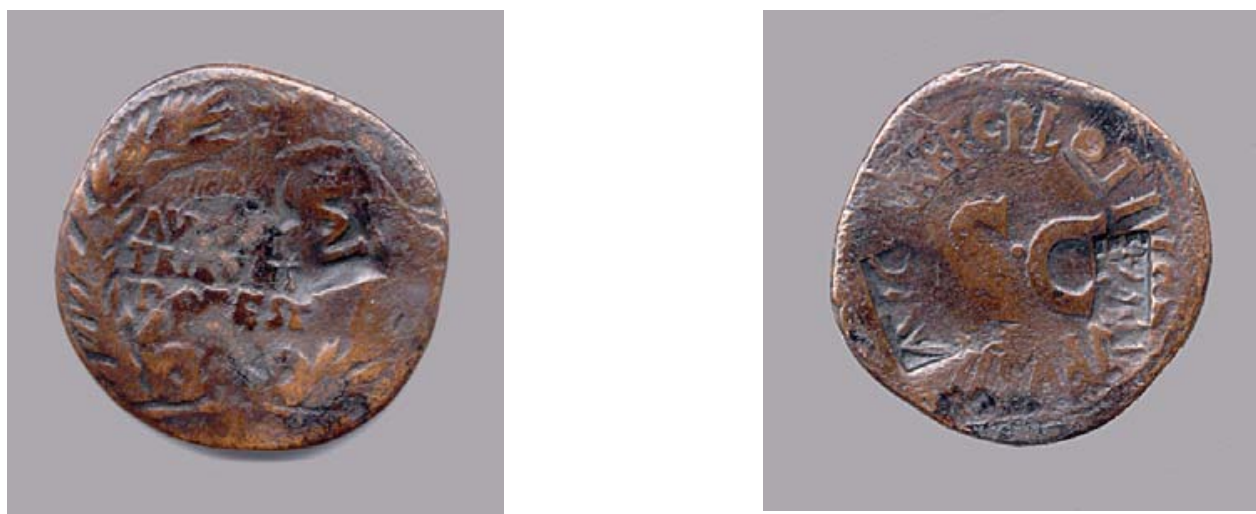

c. \& d. Durban 2004.46
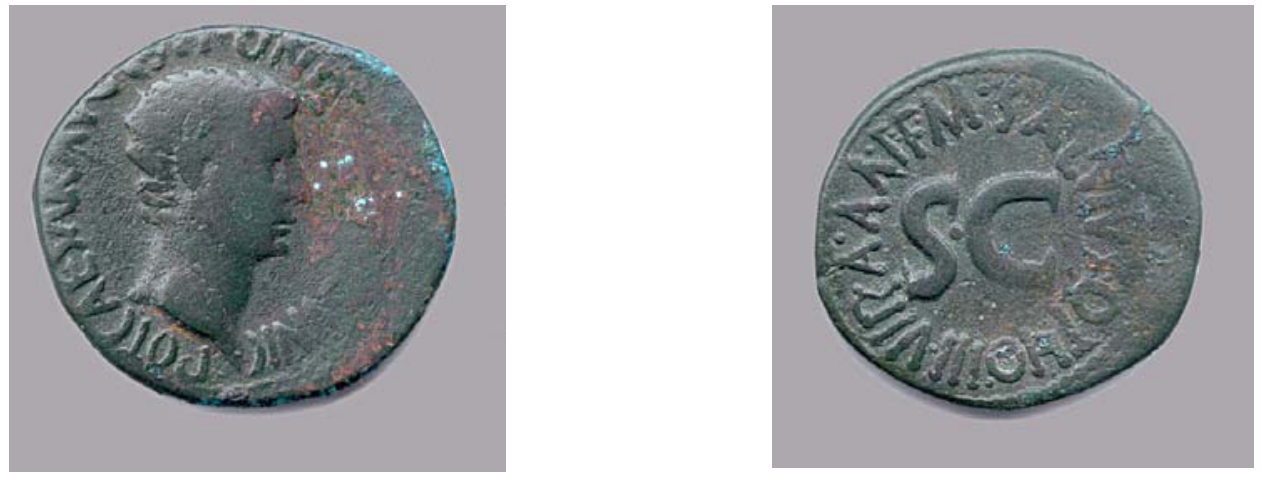

e. \& f. Durban 2004.47

\section{Plate 1}



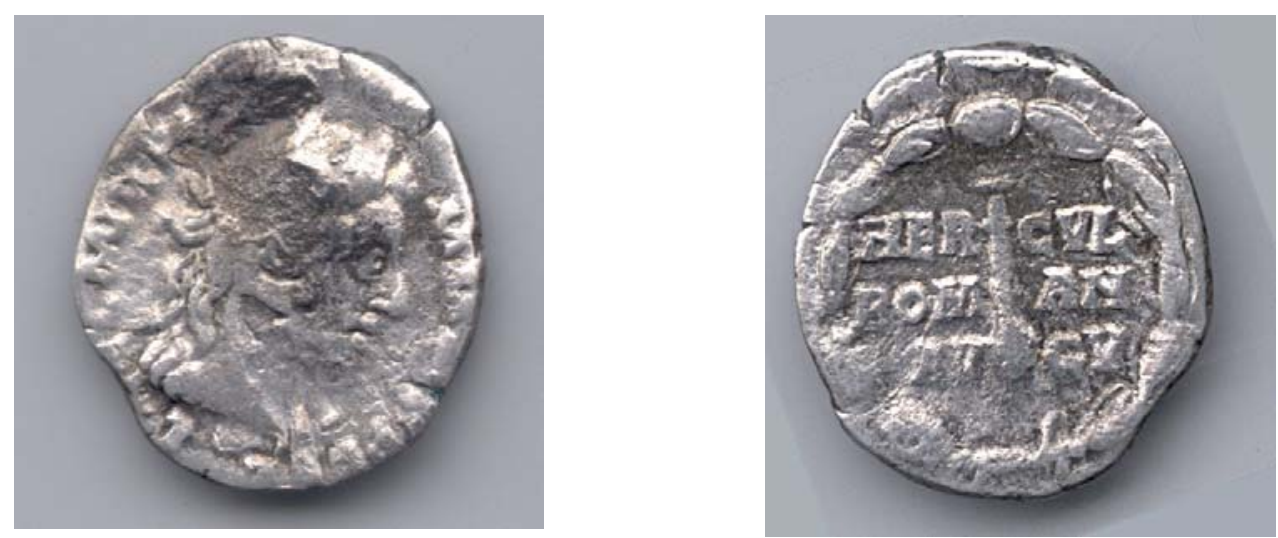

a. \& b. Durban 2004.48
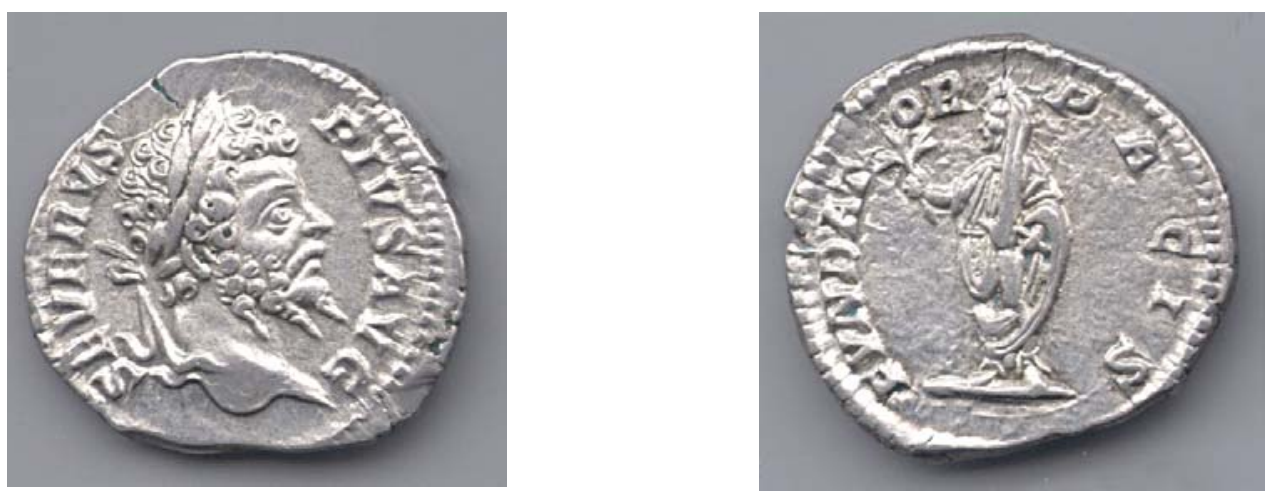

c. \& d. Durban 2004.49

Plate 2 